\title{
Correction
}

\section{Correction: Chronic Total Occlusions in Sweden - A Report from the Swedish Coronary Angiography and Angioplasty Registry (SCAAR)}

\section{The PLOS ONE Staff}

The second author's name is spelled incorrectly. The correct name is Loes P. Hoebers. The correct citation is: Råmunddal T, Hoebers LP, Henriques JPS, Dworeck C, Angerås O, et al. (2014) Chronic Total Occlusions in Sweden - A Report from the Swedish Coronary Angiography and Angioplasty Registry (SCAAR). PLoS ONE 9(8): e103850. doi:10.1371/journal.pone. 0103850

\section{Reference}

1. Råmunddal T, Hoebers L, Henriques JPS, Dworeck C, Angerås O, et al. (2014) Chronic Total Occlusions in Sweden - A Report from the Swedish Coronary Angiography and Angioplasty Registry (SCAAR). PLoS ONE 9(8): e103850. doi:10.1371/journal.pone. 0103850
Citation: The PLOS ONE Staff (2014) Correction: Chronic Total Occlusions in Sweden - A Report from the Swedish Coronary Angiography and Angioplasty Registry (SCAAR). PLoS ONE 9(10): e112370. doi:10.1371/journal.pone.0112370

Published October 27, 2014

Copyright: (๑) 2014 The PLOS ONE Staff. This is an open-access article distributed under the terms of the Creative Commons Attribution License, which permits unrestricted use, distribution, and reproduction in any medium, provided the original author and source are credited. 